\title{
A Case of Atypical Brucellosis Presented with Isolated Lymphadenopathy*
}

\author{
İole Lenfadenopatiyle Başvuran Atipik \\ Bir Bruselloz Olgusu
}

\author{
Kamuran Karaman' ${ }^{1}$ Hatice Tuba Akbayram², Sinan Akbayram', Mesut Garipardıç', Ahmet Fayik Öner ${ }^{1}$ \\ ${ }^{\prime}$ Department of Pediatric Health and Diseases, Division of Hemotology and Oncology, Yuzuncu Yil University School of Medicine, Van, Turkey \\ 2 Department of Family Medicine, Yuzuncu Yil University School of Medicine, Van, Turkey
}

* This case presentation was presented at the $4^{\text {th }}$ Peditric Hematology Symposium (May 29-June 1, 2014) and published in the abstract book.

\section{Abstract}

Brucellosis is transmitted via animal or animal products. The transmission of infection from animal to human occurs by the ways of; generally the direct contact of secretions of infected animals through the human skin which of broken integrity, consumption of unpasteurized milk and milk products, inhalation and contact with conjunctiva with infected aerosols. The infection can be presented with variable manifestations and involment of cardiovascular, central nervous system, skeletal system, skin and gastrointestinal system. It is generally a disease with good prognosis; but the complicated involvement like of bone, cardiovascular and menegial site leads to significant morbidity and mortality. Here, we presents a case of brucella lymphadenitis of 9 years old patiens in whom admitted with isolated Imphadenopathy and recovered clinically and laboratory upon starting the treatment for brucellosis.

Keywords: Brucellosis, lymphadenopathy, child

\section{Introduction}

Brucellosis is transmitted from animals or animal products. Transmission from animals to humans generally occurs through direct contact with the skin or mucosa of the infected animal, the use of raw milk and dairy products, the respiration of infected aerosols and conjunctiva contact (1). The disease can manifest itself with various signs and symptoms and through the involvement of many systems such as the cardiovas-
Özet

Bruselloz, hayvanlar ya da hayvan ürünlerinden bulaşır. Hayvanlardan insanlara bulaş, genellikle enfeksiyonlu hayvanın salgılarının bütünlüğü bozulmuş deri ya da mukozayla doğrudan teması, pastörize edilmemiş süt ve süt ürünlerinin kullanımı, enfeksiyonlu aerosollerin solunması ve konjunktiva temasıyla olmaktadır. Hastalık çok çeşitli belirti ve bulgularla, kalp damar, iskelet, sinir, deri ve sindirim dizgesi gibi birçok dizgenin tutulumuyla belirebilir. Bruselloz genellikle prognozu iyi olan bir hastalıktır ancak; kemik, kalp damar ve sinir dizgesi gibi tutulumlar önemli hastalanım ve ölüme neden olabilir. Bu yazıda izole lenfadenopatiyle getirilen, klinik ve laboratuvar bulguları tedaviyle düzelen, brusella lenfadenitli dokuz yaşındaki bir hasta sunulmuştur.

Anahtar Kelimeler: Bruselloz, lenfadenopati, çocuk

cular, musculoskeletal, nervous, skin and digestive systems. Brucellosis is generally a disease with a favorable prognosis; however, the involvement of musculoskeletal, cardiovascular and nervous systems can lead to serious morbidity and mortality (2). This study aimed at presenting a nine-year-old patient with brucella lymphadenitis that applied to hospital with isolated lymphadenitis and recovered clinically after the commencement of brucella treatment. 


\section{Case Report}

A nine-year-old male patient was brought to hospital with a complaint of swelling in the neck. Patient and family history was normal. Physical examination of the patient showed $36.5^{\circ} \mathrm{C}$ body temperature, $80 / \mathrm{min}$ pulse and $110 / 65$ $\mathrm{mmHg}$ blood pressure. Examination of the neck revealed bilateral neck lymph node enlargement, the largest of which was $2 \times 2 \mathrm{~cm}$ at the right lower mandibular region. The patient had a BCG scar, and other physical examination findings were normal. Laboratory findings were as follows: hemoglobin $13.9 \mathrm{~g} / \mathrm{dL}$, hematocrit $42 \%$, white blood cell count $8500 / \mathrm{mm}^{3}$, platelet count $353.000 / \mathrm{mm}^{3}$; blood smear found $50 \%$ polymorphonuclear leukocytes, $44 \%$ lymphocyte and $6 \%$ monocyte. PPD was measured as $1 \mathrm{~mm}$ and chest radiography was normal. No pathological finding was detected in toxoplasmosis and other infection determinants. Brucellosis agglutination was determined as $1 / 320$, and it was reported as non-caseiting granulomatous lymphadenitis following excisional biopsy. The patient, who was diagnosed clinically and serologically as acute brucellosis, was started on rifampicin (20 mg/kg/day) and doxycycline ( $5 \mathrm{mg} / \mathrm{kg} /$ day). It was confirmed that lymphadenopathies started to shrink on day 20 of the treatment and were non-palpable on day 40 . Four-month follow-up of the patient was unproblematic.

\section{Discussion}

According to frequency levels, brucellosis in Turkey is seen mostly in the Southeastern, Eastern and Central Anatolia regions (3). Since stockbreeding is common especially in the Eastern Region, cases of brucellosis can be seen year-round. In a study conducted in Van with 968 individuals, seroprevalence was found as $8.3 \%$ (4). The usual incubation period of $2-3$ weeks can take 1-4 weeks. The disease mostly manifests itself with malaise, lack of appetite, pain in the body and mild fever. Brucellosis may lead to different conditions as it is a disease that can involve all organs. Brucellosis cases with mesenteric lymphadenitis have been reported in the literature. Jayakumar et al. (5) and Fernandez et al (6). have reported in their patients taken into operation with a diagnosis of acute appendicitis that the appendix was normal and the existence of mesenteric lymphadenitis was determined and that treatment was started upon the reproduction of Brucella spp. in the blood cultures of the patients and a favorable response was received. $32 \%$ of patients with brucellosis show involvement of the digestive system (liver, gallbladder, small and large bowels, peritoneum, and pancreas) and symptoms such as stomach ache, nausea, vomiting, diarrhea, and constipation. In a retrospective study by Çataklı et al. (7), lymphadenopathy has been confirmed in $18 \%$ of $33(6)$ patients. Lymphadenopathy is seen in $10-20 \%$ cases in the course of brucellosis. Özhan et al. (8) have reported a twelve-year-old case with brucellosis-related isolated neck lymphadenitis that resembles our patient. In a study by Saça et al. (9) including 30 cases with brucellosis, joint pain has been determined to be the most frequent and fever the fifth most frequent symptom, and when system involvement has been evaluated, musculoskeletal and blood involvements have taken place on top.

Brucellosis diagnosis is made by reproducing the agent from samples like blood, bone marrow and cerebrospinal fluid or with the existence of titre 1/160 or over in tube agglutination test. The rate of culture positivity in brucellosis series in Turkey is between 12 and $70 \%$; however, it should not be forgotten that these rates can be effected by not keeping the culture samples long enough and previous antibiotic use (10). Since Brucella spp. is an intracellular bacterium, antibiotic parity that is effective intracellularly with synergism should be preferred in treatment. Single-antibiotic use may result in recurrence (11). Rifampicin and doxycycline parity was used in our case.

In conclusion, it is known that brucellosis resembles many other diseases and it is frequently seen in individuals dealing with stockbreeding and their families in our region. This case was presented in order to emphasize that brucellosis, despite being rare, should be kept in mind in the differential diagnosis of a patient with neck lymphadenitis.

Informed Consent: Written informed consent was obtained from parent of patient.

Peer-review: Externally peer-reviewed.

Author Contributions: Concept - KK, SA; Design - HTA, SA; Supervision - MG, KK, AFÖ; Collection and/or Processing - SA, KK; Analysis and/or Interpretation - SA, AFÖ, KK; Literature Review - MG, SA; Writing - KK, AFÖ, SA; Critical Review - MG, HTA, KK

Conflict of Interest: The authors have not reported a conflict of interest.

Financial Disclosure: The authors declared that they did not receive financial support.

\section{References}

1. Aktaş F, Şenol E, Yetkin A, Gürdoğan K, Ulutan F. Brusellozda klinik ve laboratuvar bulgularının hastalık stresi ile ilişkisi. Türk Mikrobiyol Cem Derg 1994;24:164-9.

2. Aygen B, Sümerkan B, Kardaş $Y$ ve ark. Bruselloz: 183 olgunun değerlendirilmesi. KLiMiK Derg 1995;8:13-6.[CrossRef]

3. Slack MPE. Gram-negative coccobacilli. Armstrong D, Cohen J (ed). Infectious disease. London: Harcourt Publishers, 1999:8.20.1-18.

4. Aksoy $H$, Erkoç $R$, Dilek $I$ ve ark. Van ve yöresinde 20 yaş ve üstü bireylerde brusella seroepidemiyolojisi 1. Ulusal Tropikal Hastalıklar Kongresi Kitabı, 1998: 270. 
5. Jayakumar RV, Al-Aska AK, Subesinghe N, Wright SG. Unusual presentation of culture positive brucellosis. Postgrad Med J 1988;64: 118-20. [CrossRef]

6. Fernandez MD, Garcia JLZ, Garcia FD, Fernandez MTC. Brucella acute abdomen mimicking appendicitis. Am J Med 2000;108:599-600. [CrossRef]

7. Çataklı T, Kılıç N, Dallar Y. Bruselloz tanılı 33 olgunun retrospektif değerlendirilmesi. Ege Tıp Derg/Ege J Med 2011;50:39-42.[CrossRef]

8. Özhan B, Kamil F, Akduman I, Ay Y, Helvacı M. A rare manifestation of brucellosis: cervical lymphadenitis. Çocuk Enfeksiyon Derg/J Ped Infect 2009;3:190-1. [CrossRef]
9. Saçar S, Hırçın D, Toprak S, Demir M, Turgut H. Otuz bruselloz olgusunun klinik değerlendirilmesi. Infeksiyon Derg/Turk J Infect 2008;22:11-4. [CrossRef]

10. Gür A, Geyik MF, Dikici B, et al. Complications of brucellosis in different age groups: a study of 283 cases in Southeastern Anatolia of Turkey. Yonsei Med J 2003;44:33-44. [CrossRef]

11. Akova M, Uzun Ö, Akalın HE, Hayran M, Unal S, Gür D. Quinolones in treatment of human brucellosis: comparative trial of ofloxacinrifampin versus doxycycline-rifampin. Antimicrob Agents Chemother 1993;37:1831-4. [CrossRef] 